\title{
Methicillin-resistant Staphylococcus aureus associated with animals and its relevance to human health
}

\author{
Annalisa Pantosti * \\ Department of Infectious, Parasitic and Immune-Mediated Diseases, Istituto Superiore di Sanità, Rome, Italy
}

Edited by:

Stefania Stefani, University of

Catania, Italy

\section{Reviewed by:}

Sabeel Padinhara Valappil, The

University of Liverpool, UK

Alexander W Friedrich, University

Hospital Groningen (UMCG),

Netherlands

${ }^{*}$ Correspondence:

Annalisa Pantosti, Department of

Infectious, Parasitic and

Immune-Mediated Diseases, Istituto

Superiore di Sanità, Viale Regina

Elena 299, 00161 Rome, Italy.

e-mail: annalisa.pantosti@iss.it
Staphylococcus aureus is a typical human pathogen. Some animal S. aureus lineages have derived from human strains following profound genetic adaptation determining a change in host specificity. Due to the close relationship of animals with the environmental microbiome and resistome, animal staphylococcal strains also represent a source of resistance determinants. Methicillin-resistant $S$. aureus (MRSA) emerged 50 years ago as a nosocomial pathogen but in the last decade it has also become a frequent cause of infections in the community. The recent finding that MRSA frequently colonizes animals, especially livestock, has been a reason for concern, as it has revealed an expanded reservoir of MRSA. While MRSA strains recovered from companion animals are generally similar to human nosocomial MRSA, MRSA strains recovered from food animals appear to be specific animal-adapted clones. Since 2005, MRSA belonging to ST398 was recognized as a colonizer of pigs and human subjects professionally exposed to pig farming. The "pig" MRSA was also found to colonize other species of farmed animals, including horses, cattle, and poultry and was therefore designated livestock-associated (LA)-MRSA. LA-MRSA ST398 can cause infections in humans in contact with animals, and can infect hospitalized people, although at the moment this occurrence is relatively rare. Other animal-adapted MRSA clones have been detected in livestock, such as ST1 and ST9. Recently, ST130 MRSA isolated from bovine mastitis has been found to carry a novel mecA gene that eludes detection by conventional PCR tests. Similar ST130 strains have been isolated from human infections in UK, Denmark, and Germany at low frequency. It is plausible that the increased attention to animal MRSA will reveal other strains with peculiar characteristics that can pose a risk to human health.

Keywords: Staphylococcus aureus, MRSA, ST398, animals, spa type

\section{INFECTIONS AND ANIMALS}

Infectious diseases have accompanied humankind since its dawn. However, it is not until the end of the last ice age, approximately 10,000 years ago when the agricultural revolution began, that humans became more exposed to the pathogens of infectious disease that have since shaped human history. In the previous era when humans were hunter-gatherers, they moved nomadically over vast territories. Then humans started breeding wild weeds and domesticating animals -sheep, goats, cattle, pigs, poultry, and horses- for food and labor. Stable settlements and proximity to animals caused pathogens to thrive and spread between animals and humans, and infectious diseases become prominent in influencing life and death (Porter, 1997). There began also the sharing of bacterial species between animals and humans, and co-evolution of pathogens with their hosts.

The heritage of the Neolithic Age continues today. It is estimated that over $60 \%$ of the emerging human pathogens come from animals (Cutler et al., 2010). To feed the growing human population, there is an increasing demand for intensive animal farming involving large numbers of animals, different species in the same area, and the use of growth promoters and antibiotics. These practices can facilitate the emergence of new pathogens, including antibiotic-resistant organisms, and their transmission to humans. In addition, food of animal origin can be a major vehicle for animal pathogens and their spread can be amplified by the market globalization.

\section{FROM STAPHYLOCOCCUS AUREUS TO METHICILLIN-RESISTANT STAPHYLOCOCCUS AUREUS}

Staphylococcal infections are of major importance in both human and veterinary medicine. Staphylococcus aureus is a major resident or transient colonizer of the skin and the mucosa of humans and primates. It occasionally lives on domestic animals, although these are usually colonized by other species of staphylococci. When $S$. aureus gains entry into the host, it is able to cause a variety of infections, from mild skin infection to life threatening invasive infections.

Staphylococcus aureus has the characteristic ability to rapidly develop resistance to virtually any antibiotic drug coming into clinical use (Pantosti et al., 2007). Resistance to methicillin - that indicates resistance to all beta-lactam agents - was first reported in 1961, the date that marks the appearance of Methicillin-resistant S. aureus (MRSA). Methicillin resistance is due to the acquisition of the mecA gene, that encodes a new protein designated 
PBP2a, belonging to a family of enzymes necessary in building the bacterial cell wall. PBP2a has a very low affinity for $\beta$-lactam antibiotics and confers resistance to methicillin and the other beta-lactams (Pantosti et al., 2007). The mecA gene is located on a mobile genetic element, named staphylococcal cassette chromosome mec (SCCmec) inserted in the S. aureus chromosome upstream orf X (Katayama et al., 2000). Different types of SCCmec can be distinguished on the basis of different key elements present, that are the mec gene complex, comprising $m e c A$ and its regulatory genes mecI and mecR 1 , and the $c c r$ genes complex comprising two different $c c r$ recombinases that are responsible for the mobility of the element (Ito et al., 2001, 2004; Ma et al., 2002). To date, the website of the International Working Group on the Staphylococcal Cassette Chromosome elements (http://www.sccmec.org/Pages/SCC_TypesEN.html, accessed on February 2, 2012) lists 11 types of SCCmec elements, originating from the combination of eight different $c c r$ genes complex and five different mec gene complex.

As MRSA is generated by the introduction of a mecA-carrying element in a methicillin-susceptible S. aureus (Enright et al., 2002), the origin of mecA has long been searched for. Couto et al. (1996) found a mecA homolog with $80 \%$ identity to the $S$. aureus gene in S. sciuri, a methicillin-susceptible Staphylococcus of rodents, and other primitive mammals. Another mecA homolog with 91\% identity with $S$. aureus mecA was found in staphylococci recovered from horses, and specifically in S. vitulinus (Schnellmann et al., 2006). According to recent data, S. fleurettii, belonging to S. sciuri group, could be the origin of mecA as this species contains mecA and the chromosomal locus surrounding mecA that are almost identical to the corresponding sequence of SCCmec (Tsubakishita et al., 2010). Taken together, these studies indicate that animal staphylococci are the likely origin and reservoir of mecA.

\section{DIFFERENT TYPES OF MRSA}

Methicillin-resistant S. aureus has long been considered the prototype of multidrug-resistant nosocomial pathogens, causing infections in hospitals and healthcare facilities. The proportion of MRSA infections has increased greatly in the last three decades and strains defined healthcare-associated MRSA (HA-MRSA) have become endemic in industrialized countries as causes of serious infections such as septicemia, pneumonia, ventilator-associated pneumonia, and surgical site infections (Diekema et al., 2001). In the US, the National Nosocomial Infections Surveillance System (NNISS) reported that in 2003 , over $60 \%$ of S. aureus isolates in ICUs were MRSA (Klevens et al., 2006). In Europe according to data collected by EARS-Net, the rate of MRSA in bloodstream infections ranges from below $1 \%$ to over $50 \%$ in different countries, with lower rates in North European countries and a higher rate in Mediterranean countries (Kock et al., 2010). At the end of the 1990s, a new generation of MRSA appeared suddenly in a different setting, the community. The new MRSA strain, designated community-acquired (CA)-MRSA, is able to cause infections in young and otherwise healthy individuals, showing an unusual virulence and capacity to spread (Deleo et al., 2010).

CA-MRSA commonly causes SSTIs with different severity degrees, from mild (furuncles or impetigo), to serious infections (necrotizing fasciitis; Miller et al., 2005), and rarely can cause a severe form of pneumonia (necrotizing pneumonia) associated with high mortality (Francis et al., 2005). CA-MRSA possesses some distinctive features with regard to HA-MRSA: such as presence of SCCmec type IV or type V and rare multi-resistance (Naimi et al., 2003). Characteristically, the large majority of CA-MRSA harbors the genes for the Panton-Valentine leukocidin (PVL), a toxin that is absent in HA-MRSA (Vandenesch et al., 2003). PVL has been considered the principal virulence determinant (Lina et al., 1999; Boyle-Vavra and Daum, 2007) or a simple marker of CA-MRSA strains (Voyich et al., 2006). In the USA, the increase in the prevalence of CA-MRSA took the shape of an epidemic, largely due to the expansion of a single clone, designated USA300 (Moran et al., 2006; Kennedy et al., 2008; Tenover and Goering, 2009). In Europe, where the prevalence of CA-MRSA infections is lower than in the USA (Del Giudice et al., 2006), the most common clone is the European ST80 clone, (Urth et al., 2005), alongside a variety of different CA-MRSA clones (Tristan et al., 2007; Sanchini et al., 2011).

Recently, MRSA emerged as a frequent colonizer of animal populations, possibly favored by the large antibiotic use in animals. In food animals, primarily in pigs, a new MRSA strain with zoonotic potential has been recognized and designated livestock-associated (LA)-MRSA. The following chapters illustrate the association between MRSA and animals and the implications for human health.

\section{STAPHYLOCOCCUS AUREUS AS AN ANIMAL-ADAPTED PATHOGEN}

The ability to colonize and produce infections in different hosts, including humans, is an important characteristic of some $S$. aureus lineages. In early studies, the available methods to type $S$. aureus were exclusively phenotypic (phage typing, biotyping, and typing of enzymes or toxins). Nevertheless, they allowed the differentiation of $S$. aureus strains into host specific subsets or ecovars, typically associated with man, poultry, sheep, goats, and cattle (Devriese, 1984), while a minority of S. aureus strains belonged to non-host specific types and were shared among different hosts. The application of molecular biology techniques confirmed these early findings, revealing that particular genetic backgrounds (clones or lineages) are associated with specific mammalian hosts (Sung et al., 2008; Cuny et al., 2010). These studies also showed that some lineages are not restricted and can be found to colonize or cause infections in a broad variety of animal species, including humans. One notable example is represented by ST398, originally defined the "pig" clone that has been recovered also from other food animals and from humans (Voss et al., 2005; Witte et al., 2007). Some primarily "human" clones are often found in animals: ST1, a frequent clone in human infections (Grundmann et al., 2010) can cause bovine mastitis (Juhasz-Kaszanyitzky et al., 2007) and is carried by pigs in Italy and other European countries (European Food Safety Authority, 2009; Franco et al., 2011).

Staphylococcus aureus adapts specifically to different animal hosts by genetically determined mechanisms that are just starting to be understood. In some cases, host specificity is determined by a selective affinity of certain bacterial receptors to proteins of the preferred host. S. aureus acquires iron, an essential bacterial nutrient, from hemoglobin, following lysis of blood red cells 
produced by $S$. aureus hemolysin. Hemoglobin is released and bound to a surface $S$. aureus receptor, the iron surface determinant B (IsdB), before being degraded. This receptor has a higher affinity for human hemoglobin than for the hemoglobin of other mammals. This explains, at least in part, why $S$. aureus thrives in the presence of human blood and why humans are generally the preferential host for S. aureus (Pishchany et al., 2010).

Recent phylogenetic studies revealed that some animal S. aureus lineages derived from human lineages. In this host-jump, S. aureus underwent genetic adaptation losing virulence factors that were useless in the new host and acquiring new characteristics. Some examples are depicted in Table $\mathbf{1}$.

The poultry ST5 lineage which spread in poultry farms worldwide (Lowder et al., 2009) has only recently diverged from the human ST5 lineage. This host switch was associated with loss of expression of several proteins that are relevant to human, but not to avian pathogenesis, including the immune evasion cluster and the staphylococcal protein A (SpA). SpA plays a major role in the pathogenesis of human staphylococcal infections; among several functions it binds the FC fragment of human IgG impairing antibody functions, but it does not bind the FC fragment of IgY, the avian analog of IgG. On the other hand, poultry ST5 has acquired novel mobile genetic elements that encode for advantageous traits for survival in an avian host, including resistance to avian phagocytes killing. Similarly, the pathogenic lineage CC133 established in small ruminants (sheep and goats) derived from human S. aureus through a combination of allelic diversification, gene decay, and acquisition of mobile genetic elements (Guinane et al., 2010). In particular, through horizontal gene transfer, this clone acquired a pathogenicity island (SaPI) encoding a novel variant of the von Willebrand factor-binding protein that has ruminant-specific coagulase activity (Viana et al., 2010).

In line with these findings, a microarray study (Sung et al., 2008) revealed differences in the frequency of specific genes carried by animal $S$. aureus and those carried by human isolates. In animal isolates, there was a low prevalence of a cluster of genes encoding proteins relevant for host immune evasion that target specifically human immune responses (van Wamel et al., 2006). One such gene is sak, coding for staphylokinase, a fibrin-specific plasminogen activator that is present in over $80 \%$ of human isolates, but is absent from some cattle and pig lineages (Monecke et al., 2007; Sung et al., 2008; Franco et al., 2011).

\section{MRSA IN COMPANION ANIMALS}

In industrialized countries, companion animals have become an integral part of the household. More than $50 \%$ of households in the USA have pets and 25\% of households in the United Kingdom have dogs (Chomel and Sun, 2011). In general, MRSA strains recovered from companion animals (cats, dogs, or horses) are different from those recovered from food animals. In the first case strains are usually similar to human HA-MRSA, while in the second case they appear to belong to specific animal-adapted clones, unrelated to the most common HA-MRSA (Table 2).

Other staphylococcal species that share with $S$. aureus the ability to acquire methicillin resistance, specifically $S$. intermedius, S. pseudintermedius, and S. schleiferi, are more common in pets (Hanselman et al., 2008, 2009). Reports of MRSA isolated from pets were sporadic until the late 1990s and were mostly related to

Table 1 | Distribution of some $S$. aureus genes among human and animal strains.

\begin{tabular}{|c|c|c|c|c|c|}
\hline \multirow[t]{2}{*}{ Gene } & \multirow[t]{2}{*}{ Function } & \multirow[t]{2}{*}{ Effect } & \multicolumn{2}{|c|}{ Presence/absence in isolates from } & \multirow[t]{2}{*}{ Reference } \\
\hline & & & Humans & Animals (species), clone & \\
\hline spa & FC binding & Impairment of antibody function & $P$ & $\begin{array}{l}A^{\circ} \text { (poultry), ST5 } \\
A^{\circ} \text { (cattle), ST151 }\end{array}$ & $\begin{array}{l}\text { Lowder et al. (2009), } \\
\text { Herron-Olson et al. (2007) }\end{array}$ \\
\hline chp & Chemotaxis inhibitor & Impairment of host native immunity & $P$ & $\begin{array}{l}\text { A (poultry), ST5 } \\
\text { A (cattle), ST151 }\end{array}$ & $\begin{array}{l}\text { Lowder et al. (2009), } \\
\text { Monecke et al. (2007), } \\
\text { Sung et al. (2008) }\end{array}$ \\
\hline scn & Complement inhibitor & Impairment of host native immunity & $P$ & $\begin{array}{l}\text { A (poultry), ST5 } \\
\text { A (cattle), ST151 }\end{array}$ & $\begin{array}{l}\text { Lowder et al. (2009), } \\
\text { Monecke et al. (2007), } \\
\text { Sung et al. (2008) }\end{array}$ \\
\hline sak & Plasminogen activator & Coagulation of plasma & $P$ & $\begin{array}{l}\text { A (cattle), ST151 } \\
\text { A (poultry, pigs), ST1 }\end{array}$ & $\begin{array}{l}\text { Lowder et al. (2009), } \\
\text { Monecke et al. (2007), } \\
\text { Sung et al. (2008), } \\
\text { Franco et al. (2011) }\end{array}$ \\
\hline$v W b p^{\text {Sov2 }}$ & 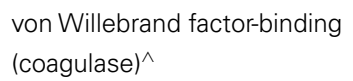 & Coagulation of plasma & A & $\mathrm{P}$ (ruminants), CC133 & Guinane et al. (2010) \\
\hline
\end{tabular}

P, present; $A$, absent.

Gene disrupted or pseudogene.

$\wedge$ Ruminant variant. 
Table 2 | Principal MRSA clones shared between animals and humans.

\begin{tabular}{|c|c|c|c|c|c|c|c|c|}
\hline Lineage & Clone* & $\begin{array}{l}\text { Companion } \\
\text { animals }\end{array}$ & Horses & Pigs & Poultry & Cattle & Humans & Reference \\
\hline $\mathrm{CC} 1$ & ST1 & & & $\bullet$ & & $\bullet$ & $\bullet$ & $\begin{array}{l}\text { Juhasz-Kaszanyitzky et al. (2007), Cuny et al. (2008), } \\
\text { Franco et al. (2011) }\end{array}$ \\
\hline CC5 & ST5 (USA100) & $\bullet$ & & $\bullet$ & $\bullet$ & $\bullet$ & $\bullet$ & $\begin{array}{l}\text { Khanna et al. (2008), Hata et al. (2010), Hasman et al. } \\
\text { (2010), McDougal et al. (2003) }\end{array}$ \\
\hline $\mathrm{CC} 8$ & ST8 (USA500) & & $\bullet$ & & & & $\bullet$ & Morgan (2008), McDougal et al. (2003) \\
\hline $\operatorname{cc9}$ & ST9 & & $\bullet$ & $\bullet$ & & & & $\begin{array}{l}\text { European Food Safety Authority (2009), Cuny et al. } \\
\text { (2008), Battisti et al. (2010) }\end{array}$ \\
\hline \multirow[t]{2}{*}{$\mathrm{CC} 22$} & ST22 (EMRSA-15) & $\bullet$ & & & & & $\bullet$ & Loeffler et al. (2005), Ellington et al. (2010) \\
\hline & ST36 (EMRSA-16) & $\bullet$ & & & & & $\bullet$ & Loeffler et al. (2005), Ellington et al. (2010) \\
\hline CC97 & ST97 & & & $\bullet$ & & & $\bullet$ & $\begin{array}{l}\text { Battisti et al. (2010), European Food Safety Author- } \\
\text { ity (2009), Gomez-Sanz et al. (2010), Monecke et al. } \\
\text { (2011) }\end{array}$ \\
\hline CC398 & ST398* & $\bullet$ & $\bullet$ & $\bullet$ & $\bullet$ & $\bullet$ & $\bullet$ & $\begin{array}{l}\text { Loeffler et al. (2009), Cuny et al. (2008), de Neeling } \\
\text { et al. (2007), Nemati et al. (2008), Vanderhaeghen } \\
\text { et al. (2010a), Kock et al. (2011) }\end{array}$ \\
\hline
\end{tabular}

${ }^{*}$ Principal ST encountered, including also single and double locus variants. The dot means present.

clinical infections. In addition, before the identification of $S$. intermedius and $S$. pseudintermedius, some misclassification may have occurred (Devriese et al., 2005). The emergence of CA-MRSA in the last decade and the importance of tracing antibiotic-resistant organisms also in the community, have prompted many studies on MRSA in pets and its possible transmission to pet owners.

According to studies performed in various countries, especially in the UK and Australia, MRSA colonization is rare in healthy pets. No MRSA was found in healthy cats in several studies (Baptiste et al., 2005; Loeffler et al., 2005; Hanselman et al., 2009), although in a recent study $2.1 \%$ of cats presented to veterinary clinics in Greater London area were colonized by MRSA (Loeffler et al., 2011). In dogs in a household or at admission to a veterinary hospital, colonization rates varied from 0 to 2.1\% (Bagcigil et al., 2007; Boost et al., 2008; Hanselman et al., 2008, 2009; Loeffler et al., 2011). In some particular settings, e.g., dogs in a rescue shelter (Loeffler et al., 2010) or in a veterinary hospital (Loeffler et al., 2005), a high MRSA colonization rate, up to $9 \%$, was found.

Methicillin-resistant $S$. aureus infections in pets are mainly represented by skin and soft tissue infections and are sometimes associated with veterinary surgeries. In a large study in the UK, MRSA was recovered from $1.5 \%$ of samples from infected animals (Rich and Roberts, 2004). In several studies, dogs appear to have more MRSA infections than cats (Morgan, 2008), but as there are no direct comparative studies, any implication of different susceptibility to MRSA infections between these animal species should be verified. The MRSA types recovered from cats and dogs are similar to those affecting humans, with a similar regional distribution (Table 2). For instance, in the USA the most common MRSA type in pets is the clone identified as USA100 (ST5), which is also the most common HA-MRSA clone in humans (McDougal et al., 2003). In the United Kingdom the most common clones are those identified as EMRSA-15 (ST22) and EMRSA-16 (ST36) that are prevalent in UK hospitals (Ellington et al., 2010). Recently, dogs have been found to be colonized by the livestock-associated (LA)MRSA clone characteristic of food animals and identified as ST398 (Loeffler et al., 2009).

Horses are colonized by MRSA in a percentage ranging from 0 to $11 \%$ (Vengust et al., 2006; Bagcigil et al., 2007; Loeffler et al., 2011). In a large study of colonization in Canada involving over 2,000 horses, $2.7 \%$ were found to be colonized by MRSA, mainly intranasally (Weese et al., 2005) while studies performed at equine hospitals showed a higher rate (Baptiste et al., 2005). Sporadic cases and outbreak of MRSA infections in horses were reported in large establishments or post-operatively in veterinary hospitals (Weese et al., 2005; Morgan, 2008).

Horses, differently from pets, are colonized or infected by MRSA types quite different from the lineages predominant in humans in the corresponding areas (Loeffler and Lloyd, 2010). Horse MRSA commonly belong to ST8 and related STs within clonal complex (CC) 8. A typical horse clone is USA500 (Morgan, 2008), that emerged as an HA-MRSA clone in the USA but is now infrequently recovered in human patients (McDougal et al., 2003). More recently, studies from Europe and Canada reported horses to be colonized by LA-MRSA ST398 (Cuny et al., 2008; Tokateloff et al., 2009; Table 2).

\section{TRANSMISSION OF MRSA BETWEEN HUMANS AND COMPANION ANIMALS}

Transmission of bacterial strains between companion animals and their owners has been demonstrated in several instances. Molecular analyses have shown the presence of indistinguishable MRSA strains in pets and humans living in the same household, and have suggested, but not definitely proved, the direction of transmission 
(Weese, 2010). As the isolates from cats and dogs resemble nosocomial MRSA, it is usually assumed that companion animals acquire MRSA from humans. Both humans and animals are more often colonized than infected and both can act as reservoirs of MRSA for recirculation of strains inside the household (Morgan, 2008). According to a study performed in Canada and in the US, the owners of companion animals have a MRSA colonization rate $(18 \%)$ significantly higher than the general population (1-2\%) although they do not appear to be at an increased risk for MRSA infections (Faires et al., 2009). In a nursing home for the elderly in UK patients, staff, and the resident cat were all colonized by the same MRSA strain. The cat harbored the MRSA strain on the fur and paws and was the most probable vehicle of MRSA transmission in the nursing home (Scott et al., 1988). In a veterinary hospital the transmission of an EMRSA-15 (ST22) strain from infected dogs to staff members has been demonstrated by molecular typing methods (Baptiste et al., 2005). Pets can be also colonized by CA-MRSA, as the spread of a PVL-positive CA-MRSA strain in a household in the Netherlands was shown to involve also the family dog (van Duijkeren et al., 2005).

Methicillin-resistant $S$. aureus transmission from horses to humans (and sometimes vice-versa) is also well documented, especially with regard to professionals caring for infected animals in veterinary hospitals. Staff caring for an MRSA-infected foal experienced skin infections due to the characteristic equine strain USA500, the same carried by the foal (Weese et al., 2006).

\section{MRSA IN FOOD ANIMALS: LA-MRSA ST398}

In 2004, a baby and her parents who lived on a pig farm in the Netherlands were unexpectedly found to be colonized by MRSA. Other pig farmers and their close contacts, as well as one pig were found colonized (Voss et al., 2005). The colonization rate in pig farmers was found to be $23 \%$, a figure 100 times higher than the normal colonization rate in the Netherlands. All MRSA isolates were found to share similar characteristics, such as non-typeability by PFGE and identical spa type. Similar findings in pigs and pig farmers were reported from France (Armand-Lefevre et al., 2005). The "pig MRSA" was found to belong to a unique MRSA clone, ST398, and to a group of related spa types.

Subsequent studies demonstrated that the presence of the "pig MRSA" in the Netherlands and France was not an exceptional occurrence, as this clone was recovered from pigs in several European countries (Guardabassi et al., 2007; Vanderhaeghen et al., 2010b). In addition, MRSA ST398 was shown to colonize other species of livestock besides swine (Table 2); it was thus more appropriately designated LA-MRSA. The reported carriage rates of LA-MRSA ST398 in pigs varied according to the geographical area and the type of study: from 1\% in Denmark (Guardabassi et al., 2007), to $40 \%$ in Belgium and the Netherlands (de Neeling et al., 2007; Vanderhaeghen et al., 2010b).

In a study funded by the European Food Safety Agency (EFSA), conducted in 2008, 24 European countries were involved in an active survey of MRSA in the dust of the environment of pig holdings as an indication of pig colonization. Overall, MRSA were found in pig holdings of 17 countries, with a prevalence varying between countries from 1 to $50 \%$ of the holdings sampled. Generally, countries with a higher density of pig farming were also countries with a higher recovery rate of MRSA (European Food Safety Authority, 2009). In this survey, spa types related to ST398 were, as expected, largely dominant; however, different clones, such as ST1, ST9, and ST97, were also found associated with pig carriage, although at a much lower frequency (Figure 1).

The presence of LA-MRSA ST398 in pigs is not exclusive to Europe, as a high rate of ST398 colonization was also found in pigs in Canada (Khanna et al., 2008) and in the US (Smith et al., 2009).

Other MRSA clones besides ST398 have been found to colonize pigs, generally with a regional distribution (Table 2). Studies performed in China reported the presence of ST9 colonizing pigs and workers (Wagenaar et al., 2009). In other areas, common human clones were identified in pigs, such as USA100 (ST5) in Canada (Khanna et al., 2008) and recently, ST22 in Ireland (Horgan et al., 2011). In Italy, pigs at the slaughterhouse were found to be colonized by different clones of MRSA besides ST398, including t127/ST1, ST9, and ST97 (Battisti et al., 2010). ST1 is a common human clone, although it is frequently recovered in Italian hospitals in recent years (Monaco et al., 2010). It is possible that the recovery of human clones in pigs represents human-to-pig contamination, but it is also possible that some strains, such as the $t 127 / S T 1$ clone are in fact animal-adapted strains of ancient human origin.

Despite the high rate of colonization in pigs, LA-MRSA ST398 has only sporadically been reported to cause clinical infections in this animal species (Weese, 2010): in pigs infections are rarely caused by $S$. aureus, the most common staphylococcal pathogen being $S$. hyicus.

The contamination of food products by animal MRSA is a big threat, as it has a potential for wide dissemination in the general population (Kluytmans, 2010). A study performed in the Netherlands found that $11 \%$ of raw meat samples from the retail market (including pork, beef, veal, lamb, and chicken) was contaminated by MRSA, represented mainly by MRSA ST398 (de Boer et al., 2009). A study from South Italy reported the presence of MRSA of spa types corresponding to ST398 in mozzarella cheese products (Crisetti et al., 2011).

LA-MRSA ST398 has been isolated not only from pigs, but also from other animal species, as already mentioned, including dogs, horses, calves, and poultry (Cuny et al., 2008; Hasman et al., 2010; Huber et al., 2010; Loeffler and Lloyd, 2010). In a study from Belgium, 12\% of the isolates obtained in 2006 from healthy chickens were MRSA that belonged to spa types associated with ST398 (Nemati et al., 2008; Table 2).

\section{MICROBIOLOGICAL, MOLECULAR, AND VIRULENCE CHARACTERISTICS OF LA-MRSA ST398}

LA-MRSA strains were initially distinguished by their peculiar resistance to digestion by $S m a I$, the restriction enzyme most frequently used for PFGE typing of S. aureus (Chung et al., 2000), due to the presence of a new methylation enzyme protecting restriction sites (Bens et al., 2006). Otherwise, LA-MRSA were perfectly typeable by current molecular methods: they were associated with a specific group of spa types with related repeat sequences, including t011, t034, t108, and t899 (Vanderhaeghen et al., 2010b; Figure 1) and belonged to ST398, a clone historically quite rare 


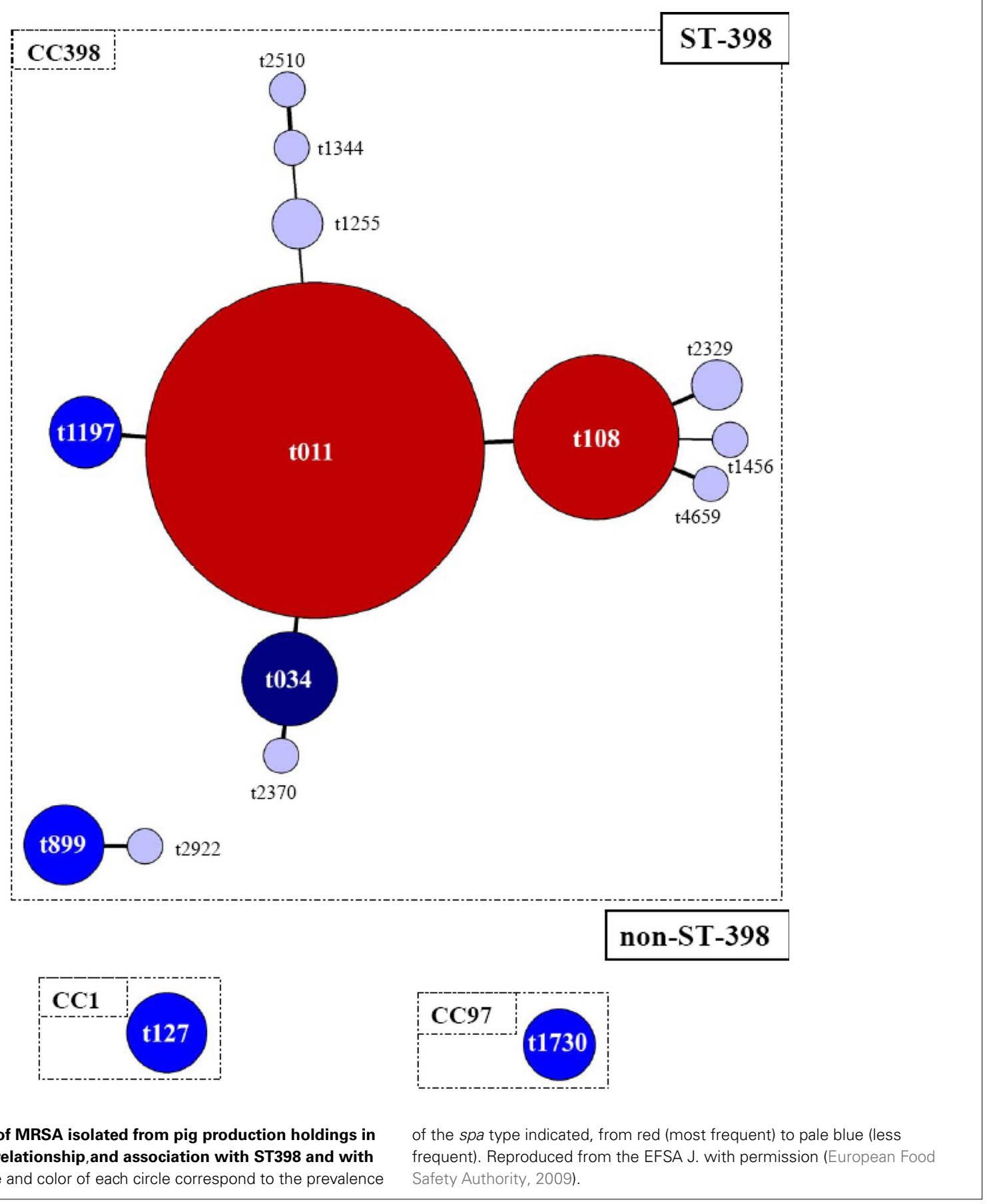

FIGURE 1 | spa types of MRSA isolated from pig production holdings in Europe, their genetic relationship, and association with ST398 and with less frequent CCs. Size and color of each circle correspond to the prevalence frequent). Reproduced from the EFSA J. with permission (European Food Safety Authority, 2009) in humans that did not derive from the most common MRSA lineages. Characteristically, LA-MRSA ST398 strains carry SCCmec type type IV or, more frequently, type V (Monecke et al., 2011). The presence of these SCCmec types in LA-MRSA is shared with CAMRSA and suggests a transmission of genetic elements between these two MRSA groups. However, differently from CA-MRSA, ST398 generally does not possess the phage-encoded PVL-genes, that contribute to the virulence of the former. Exceptions involve strains of human infections that may have acquired PVL-genes from human MRSA: one patient from the Netherlands and two patients from Sweden had infections associated with PVL-positive ST398 (van Belkum et al., 2008; Welinder-Olsson et al., 2008). Also sporadic ST398 MRSA from China has been found to be PVLpositive (Yu et al., 2008; Stegger et al., 2010). No specific virulence factor characteristic of ST398 has been identified so far (Monecke et al., 2011).

LA-MRSA ST398 is generally susceptible to antibiotics other than beta-lactams, but it is characteristically resistant to tetracycline, which suggests that heavy tetracycline use in the pig industry may have favored the emergence of this clone. A recent study 
Table 3 | Prevalence of MRSA and ST398 MRSA carriage in different healthy populations, in patients, and among clinical isolates.

\begin{tabular}{|c|c|c|c|c|c|}
\hline Population & Country & No. of subjects & MRSA & ST398 & Reference \\
\hline \multicolumn{6}{|l|}{ CARRIAGE } \\
\hline Pig farmers & Netherlands & 26 & $23 \%$ & $23 \%$ & Voss et al. (2005) \\
\hline Veterinarians & International (mainly from USA) & 345 & $7.0 \%$ & 0 & Hanselman et al. (2006) \\
\hline Pig veterinarians & International (mainly from Europe) & 235 & $14.0 \%$ & $13.1 \%$ & Wulf et al. (2008b) \\
\hline Veterinarians and veterinary personnel & Czech Republic & 280 & $0.7 \%$ & 0 & Zemlickova et al. (2009) \\
\hline \multirow[t]{2}{*}{ Veterinarians } & Belgium & 146 & $9.5 \%$ & $7.5 \%$ & Garcia-Graells et al. (2012) \\
\hline & Denmark & 143 & $1.4 \%$ & $1.4 \%$ & \\
\hline Pig farmers & Belgium & 127 & $37.8 \%$ & $37.8 \%$ & Denis et al. (2009) \\
\hline Pig farmers* & Germany & 113 & & $86 \%$ & Cuny et al. (2009) \\
\hline Family members & & 116 & & $4.3 \%$ & \\
\hline Pig veterinarians & & 49 & & $45 \%$ & \\
\hline Pupils (10-16 years) & & 462 & & $<1 \%$ & \\
\hline Pig workers & USA & 20 & $45 \%$ & $45 \%$ & Smith et al. (2009) \\
\hline Pig farmers & Ireland & 100 & $2 \%$ & 0 & Horgan et al. (2011) \\
\hline Patients at admission & Germany & 834 & $71 \%$ & $25 \%$ & Kock et al. (2011) \\
\hline \multicolumn{6}{|l|}{ CLINICAL SAMPLES } \\
\hline Clinical MRSA isolates & Europe & 8,262 & & $1.7 \%$ & van Cleef et al. (2011) \\
\hline
\end{tabular}

'MRSA resistant to Smal digestion or belonging to specific spa types are included under ST398.

${ }^{*}$ Farmers exposed to MRSA-positive pigs.

showed that the addition of tetracycline or zinc in animal feed increased the number of ST398 bacterial cells in pigs' nostrils although it had no effect on MRSA transmission (Moodley et al., 2011). LA-MRSA ST398 strains have been found to carry previously unidentified resistance genes, such as a novel trimethoprim resistance gene, $d f r K$, (Kadlec and Schwarz, 2010) and a novel gene, $v g a(\mathrm{C})$, encoding an $\mathrm{ABC}$ efflux pumps and conferring resistance to streptogramins and lincosamides (Kadlec and Schwarz, 2009). In addition, an isolate from the nose of a pig was found to carry the multidrug resistance gene $c f r$ (Kehrenberg et al., 2009) that is able to confer resistance to five different antibiotic classes, including linezolid, a "last-resource" antibiotic for serious infections due to multidrug-resistant Gram-positive bacteria. Due to their characteristic multi-host specificity, ST398 strains can represent an efficient vehicle of these resistant determinants that are plasmid-encoded, favoring their transmission and spread.

\section{LA-MRSA ST398 CARRIAGE AND INFECTIONS IN HUMANS}

Before the "epidemic" of pig colonization, ST398 isolates were rarely reported from human colonization or infection. After the first report from the Netherlands, many studies from Europe and other areas indicated that living or working on a farm was a risk factor for acquiring MRSA (Table 3). A case-control study performed in the Netherlands showed that carriers of non-typeable MRSA were more often pig or cattle farmers and that the density of non-typeable MRSA isolates corresponded to the density of pig farming (van Loo et al., 2007). In Belgium 37.8\% of pig farmers were found colonized by ST398 (Denis et al., 2009); in Germany $86 \%$ of pig farmers and $45 \%$ of veterinarians caring for pigs were colonized (Cuny et al., 2009). Family members that were not directly exposed to pigs were colonized in a lower percentage (Cuny et al., 2009), indicating that inter-human transmission can occur but at low frequency. Veterinarians and other attendees of an international conference on pig health in Denmark were sampled for MRSA carriage and $12.5 \%$ were found to carry MRSA that mostly belonged to spa types corresponding to ST398 (Wulf et al., 2008a).

In Ontario (Canada), 20\% of pig farmers were colonized by MRSA and a correlation was noted between the presence of MRSA in pigs and humans on farms (Khanna et al., 2008).

Infection can follow colonization and LA-MRSA ST398 has been found to be associated with human infections (Krziwanek et al., 2009), including serious forms such as deep abscesses, cellulitis, necrotizing fasciitis (Pan et al., 2009; Soavi et al., 2010), and bacteremia (van der Mee-Marquet et al., 2011). A survey carried out in 17 European countries in 2007 on the prevalence of ST398 among MRSA isolates from human infections, revealed that the highest proportion of ST398 was found in the Netherlands and in Belgium, while in the other countries the proportion was $<2 \%$ (van Cleef et al., 2011; Table 3). A small hospital outbreak due to ST398 occurred in Denmark in 2007 (Wulf et al., 2008a), indicating that this clone is capable of interhuman spread outside the farming setting, although this phenomenon is currently limited. In a recent study, $25 \%$ of patients admitted to a University Hospital in 2008-2009 in a German region with high a density of pig farming carried MRSA of spa types associated with ST398 and a number of clinical infections due to this clone were detected (Kock et al., 2011). According to a Dutch study, ST398 seems to be less transmittable inside hospitals than non-ST398 MRSA (Wassenberg et al., 2011). It could be speculated that the scarce propensity of LA-MRSA to spread in hospitals may be due to its susceptibility to antibiotics other than beta-lactams compared to typical HA-MRSA. However, the possibility that LA-MRSA may acquire other resistant traits and pose a greater risk to the human population cannot be dismissed. 


\section{MRSA IN BOVINE MASTITIS}

Staphylococcus aureus is one of the most important bacterial pathogens in bovine mastitis, a disease that causes significant economical losses in the milk industry; thus, S. aureus in general and MRSA in particular have been the focus of several studies in dairy cattle. The first report of MRSA in bovine mastitis milk comes from Belgium where in 1972 Devriese and Hommez isolated strains that, using biotyping methods, appeared to be of human origin (Devriese and Hommez, 1975). After this report, and until recently, MRSA was only sporadically isolated from cow milk. In the Republic of Korea a small proportion ( $0.4 \%$ ) of MRSA was found among 3047 bacterial isolates from bovine mastitis milk samples obtained between 1997 and 2004 (Moon et al., 2007). In Switzerland MRSA were found in $1.4 \%$ of mastitis milk samples (Huber et al., 2010) and in Hungary MRSA characterized by spa type t127 and ST1, of likely human origin, was recovered in $4 \%$ of samples from cows with subclinical mastitis. In this last study, transmission of MRSA to a farmer working in close contact with bovines was also demonstrated (Juhasz-Kaszanyitzky et al., 2007). A study from Japan examined 363 S. aureus from bovine milk: of these, only four were MRSA, all belonging to CC5 (Hata et al., 2010). In Belgium MRSA was found in nearly $10 \%$ of the farms where $S$. aureus mastitis was present. This comparatively high prevalence was associated with the finding that all isolates were LA-MRSA ST398 (Vanderhaeghen et al., 2010a; Table 2).

Few studies dealt with colonization of healthy cattle: a study from Switzerland only found MRSA in 1\% of nasal swabs from calves and in $0.25 \%$ of nasal swabs from cattle (Huber et al., 2010). In this study the MRSA isolates from calves were ST398, providing evidence that LA-MRSA ST398 can colonize also cattle, although the colonization rate is much lower than in pigs (Table 2).

\section{A NEW mecA GENE IN BOVINE ISOLATES}

A recently published article (Garcia-Alvarez et al., 2011) reported the presence of MRSA strains with unusual features in bovine milk samples from the UK. These strains belonged mainly to CC130 (more rarely to CC425) and carried a novel mecA gene that was only $70 \%$ identical at the nucleotide level to the classical mecA gene, escaping detection by routine PCR assays. Similarly, the encoded PBP2a protein was only $63 \%$ identical to the classical PBP2a protein and could not be detected by the commercially available antibody-based assays. The novel mecA was named mec $A_{\mathrm{LGA} 251}$, after the designation of the bovine strain where it was identified for the first time. In turn mec $A_{\mathrm{LGA} 251}$ was part of a novel SCCmec element, identified as type XI. Other distinguished features of the SCCmec type XI are the presence of a mec complex that has a different organization from other SCCmec elements including also the beta-lactamase resistance gene blaZ, and the presence of an arsenic resistance operon.

Although previously CC130 had been associated only with methicillin-susceptible $S$. aureus from animals, isolates with the same novel mec $A_{\mathrm{LGA} 251}$ were recovered from human clinical infections in the UK and Denmark. The ability of these strains to cause infections in humans was confirmed by a concurrent report describing two patients infected with similar strains in Ireland (Shore et al., 2011) and by another study from Germany where
11 CC130 strains carrying SCCmec type XI and mec $A_{\mathrm{LGA} 251}$ were identified out of a collection of 12,691 MRSA obtained in 2006-2011 (Cuny et al., 2011).

It is possible that these strains had been circulating for some time among cattle: for instance in 2003 a report from Korea described some MRSA strains from dairy cattle with low-level resistance to oxacillin that were $m e c A$-negative (Lee, 2003). Studies to investigate these findings further were not performed, but it is plausible to speculate that these strains carried the mec $A_{\mathrm{LGA} 251}$ gene or a similar variant.

The strains with the novel mecA are a new example of LAMRSA. At the moment they do not seem to pose a great risk, but their evolution is unpredictable: they could become better able to colonize, more resistant, or more pathogenic (Fluit, 2011). Continuous surveillance is necessary to promptly detect new types of MRSA from animals and to evaluate their impact on human health.

\section{CONCLUSION}

Methicillin-resistant $S$. aureus made its first appearance as the resistant variant of $S$. aureus 50 years ago and has since established as a typical multi-resistant nosocomial pathogen (Jevons, 1961). In the last two decades, new generations of MRSA have emerged, with the distinctive ability to occupy new niches, specifically the human community and food-producing animals. The risk of the presence of MRSA in food animals is clearly associated with the transfer of these microorganisms to humans. If these new MRSA enter hospitals, they will find frail patients who will be easily infected.

Phylogenetic studies revealed that some lineages of animaladapted staphylococci originated from human strains following profound genetic modifications, and that today these animaladapted strains can be transmitted back to humans. Both wild and food animals are in contact with the large microbiome and resistome pools of the environment and can therefore carry new strains and become their vehicle to the human community. Different staphylococcal species present in animals and the environment represent a large reservoir of resistance genes, from which MRSA has already picked not only the mec gene, but also other resistance determinants. The new MRSA from animals may be able to convey to humans novel resistant determinants and novel virulence factors.

While in hospitals the proportion of MRSA is clearly associated with patterns of high antibiotic consumption, it is unclear if the emergence of animal strains has been driven by high or inappropriate antibiotic consumption in the animal farming setting. However, the control of antibiotic use appears to be one of the few possible interventions today to reduce the spread and transmission of MRSA. As for MRSA colonizing food animals, good farming practices also appear to be essential in the control of the spread of MRSA.

\section{ACKNOWLEDGMENTS}

I wish to thank Monica Monaco and Andrea Sanchini for their help with the literature search and for useful discussion. This study was supported in part by a grant from Ministero della Salute (CCM). 


\section{REFERENCES}

Armand-Lefevre, L., Ruimy, R., and Andremont, A. (2005). Clonal comparison of Staphylococcus aureus isolates from healthy pig farmers, human controls, and pigs. Emerging Infect. Dis. 11, 711-714.

Bagcigil, F. A., Moodley, A., Baptiste, K. E., Jensen, V. F., and Guardabassi, L. (2007). Occurrence, species distribution, antimicrobial resistance and clonality of methicillin- and erythromycinresistant staphylococci in the nasal cavity of domestic animals. Vet. Microbiol. 121, 307-315.

Baptiste, K. E., Williams, K., Willams, N. J., Wattret, A., Clegg, P. D., Dawson, S., Corkill, J. E., O’Neill, T., and Hart, C. A. (2005). Methicillinresistant staphylococci in companion animals. Emerging Infect. Dis. 11, 1942-1944.

Battisti, A., Franco, A., Merialdi, G., Hasman, H., Iurescia, M., Lorenzetti, R., Feltrin, F., Zini, M., and Aarestrup, F. M. (2010). Heterogeneity among methicillin-resistant Staphylococcus aureus from Italian pig finishing holdings. Vet. Microbiol. 142, 361-366.

Bens, C. C., Voss, A., and Klaassen, C. H. (2006). Presence of a novel DNA methylation enzyme in methicillinresistant Staphylococcus aureus isolates associated with pig farming leads to uninterpretable results in standard pulsed-field gel electrophoresis analysis. J. Clin. Microbiol. 44, 1875-1876.

Boost, M. V., O’Donoghue, M. M., and James, A. (2008). Prevalence of Staphylococcus aureus carriage among dogs and their owners. Epidemiol. Infect. 136, 953-964.

Boyle-Vavra, S., and Daum, R. S. (2007). Community-acquired methicillinresistant Staphylococcus aureus: the role of Panton-Valentine leukocidin. Lab. Invest. 87, 3-9.

Chomel, B. B., and Sun, B. (2011). Zoonoses in the bedroom. Emerging Infect. Dis. 17, 167-172.

Chung, M., de Lencastre, H., Matthews, P., Tomasz, A., Adamsson, I., Aires de Sousa, M., Camou, T., Cocuzza, C., Corso, A., Couto, I., Dominguez, A., Gniadkowski, M., Goering, R., Gomes, A., Kikuchi, K., Marchese, A., Mato, R., Melter, O., Oliveira, D., Palacio, R., Sa-Leao, R., Santos Sanches, I., Song, J. H., Tassios, P. T., and Villari, P. (2000). Molecular typing of methicillin-resistant Staphylococcus aureus by pulsed-field gel electrophoresis: comparison of results obtained in a multilaboratory effort using identical protocols and
MRSA strains. Microb. Drug Resist. 6, 189-198.

Couto, I., de Lencastre, H., Severina, E., Kloos, W., Webster, J. A., Hubner, R. J., Sanches, I. S., and Tomasz, A. (1996). Ubiquitous presence of a $\operatorname{mec} A$ homologue in natural isolates of Staphylococcus sciuri. Microb. Drug Resist. 2, 377-391.

Cuny, C., Friedrich, A., Kozytska, S., Layer, F., Nubel, U., Ohlsen, K., Strommenger, B., Walther, B., Wieler, L., and Witte, W. (2010). Emergence of methicillin-resistant Staphylococcus aureus (MRSA) in different animal species. Int. J. Med. Microbiol. 300, 109-117.

Cuny, C., Layer, F., Strommenger, B., and Witte, W. (2011). Rare occurrence of methicillin-resistant Staphylococcus aureus CC130 with a novel mecA homologue in humans in Germany. PLoS ONE 6, e24360. doi:10.1371/journal.pone.0024360

Cuny, C., Nathaus, R., Layer, F., Strommenger, B., Altmann, D., and Witte, W. (2009). Nasal colonization of humans with methicillin-resistant Staphylococcus aureus (MRSA) CC398 with and without exposure to pigs. PLoS ONE 4, e6800. doi:10.1371/journal.pone.0006800

Cuny, C., Strommenger, B., Witte, W., and Stanek, C. (2008). Clusters of infections in horses with MRSA ST1, ST254, and ST398 in a veterinary hospital. Microb. Drug Resist. 14, 307-310.

Cutler, S. J., Fooks, A. R., and van der Poel, W. H. (2010). Public health threat of new, reemerging, and neglected zoonoses in the industrialized world. Emerging Infect. Dis. $16,1-7$.

Crisetti, E., Cataleta, A., Onni, T., Cafiero, M. A., Tola, S., and La Salandra, G. (2011). Occurrence of methicillin-resistant Staphylococcus aureus in dairy products from the Apulia region, Italy. Abstracts of the 21st European Congress of Clinical Microbiology and Infectious Diseases (ECCMID) (Milan), Clin. Microbiol. Infect. abstr. 17, P899.

de Boer, E., Zwartkruis-Nahuis, J. T., Wit, B., Huijsdens, X. W., de Neeling, A. J., Bosch, T., van Oosterom, R. A., Vila, A., and Heuvelink, A. E. (2009). Prevalence of methicillin-resistant Staphylococcus aureus in meat. Int. J. Food Microbiol. 134, 52-56.

de Neeling, A. J., van den Broek, M. J., Spalburg, E. C., van SantenVerheuvel, M. G., Dam-Deisz, W. D., Boshuizen, H. C., van de Giessen, A. W., van Duijkeren, E., and Huijsdens, X. W. (2007). High prevalence of methicillin resistant Staphylococcus aureus in pigs. Vet. Microbiol. 122, 366-372.

Del Giudice, P., Blanc, V., Durupt, F., Bes, M., Martinez, J. P., Counillon, E., Lina, G., Vandenesch, F., and Etienne, J. (2006). Emergence of two populations of methicillinresistant Staphylococcus aureus with distinct epidemiological, clinical and biological features, isolated from patients with community-acquired skin infections. Br. J. Dermatol. 154, 118-124.

Deleo, F. R., Otto, M., Kreiswirth, B. N., and Chambers, H. F. (2010). Community-associated meticillinresistant Staphylococcus aureus. Lancet 375, 1557-1568.

Denis, O., Suetens, C., Hallin, M., Catry, B., Ramboer, I., Dispas, M., Willems, G., Gordts, B., Butaye, P., and Struelens, M. J. (2009). Methicillin-resistant Staphylococcus aureus ST398 in swine farm personnel, Belgium. Emerging Infect. Dis. 15, 1098-1101.

Devriese, L. A. (1984). A simplified system for biotyping Staphylococcus aureus strains isolated from animal species. J. Appl. Bacteriol. 56, 215-220.

Devriese, L. A., and Hommez, J. (1975). Epidemiology of methicillinresistant Staphylococcus aureus in dairy herds. Res. Vet. Sci. 19, 23-27.

Devriese, L. A., Vancanneyt, M., Baele, M., Vaneechoutte, M., De Graef, E., Snauwaert, C., Cleenwerck, I., Dawyndt, P., Swings, J., Decostere, A., and Haesebrouck, F. (2005). Staphylococcus pseudintermedius sp. nov., a coagulase-positive species from animals. Int. J. Syst. Evol. Microbiol. 55, 1569-1573.

Diekema, D. J., Pfaller, M. A., Schmitz, F. J., Smayevsky, J., Bell, J., Jones, R. N., and Beach, M. (2001). Survey of infections due to Staphylococcus species: frequency of occurrence and antimicrobial susceptibility of isolates collected in the United States, Canada, Latin America, Europe, and the Western Pacific region for the SENTRY Antimicrobial Surveillance Program, 1997-1999. Clin. Infect. Dis. 32(Suppl. 2), S114-S132.

Ellington, M. J., Hope, R., Livermore, D. M., Kearns, A. M., Henderson, K., Cookson, B. D., Pearson, A., and Johnson, A. P. (2010). Decline of EMRSA-16 amongst methicillinresistant Staphylococcus aureus causing bacteraemias in the UK between 2001 and 2007. J. Antimicrob. Chemother. 65, 446-448.

Enright, M. C., Robinson, D. A., Randle, G., Feil, E. J., Grundmann, H., and Spratt, B. G.
(2002). The evolutionary history of methicillin-resistant Staphylococcus aureus (MRSA). Proc. Natl. Acad. Sci. U.S.A. 99, 7687-7692.

European Food Safety Authority. (2009). Analysis of the baseline survey on the prevalence of methicillin-resistant Staphylococcus aureus (MRSA) in holdings with breeding pigs, in the EU, 2008. Part A: MRSA prevalence estimates. EFSA J. 7, 1376.

Faires, M. C., Tater, K. C., and Weese, J. S. (2009). An investigation of methicillin-resistant Staphylococcus aureus colonization in people and pets in the same household with an infected person or infected pet. $J$. Am. Vet. Med. Assoc. 235, 540-543.

Fluit, A. C. (2011). What to do with MRSA with a novel mec gene? Lancet Infect. Dis. 11, 580-581.

Francis, J. S., Doherty, M. C., Lopatin, U., Johnston, C. P., Sinha, G., Ross, T., Cai, M., Hansel, N. N., Perl, T., Ticehurst, J. R., Carroll, K., Thomas, D. L., Nuermberger, E., and Bartlett, J. G. (2005). Severe community-onset pneumonia in healthy adults caused by methicillin-resistant Staphylococcus aureus carrying the PantonValentine leukocidin genes. Clin. Infect. Dis. 40, 100-107.

Franco, A., Hasman, H., Iurescia, M., Lorenzetti, R., Stegger, M., Pantosti, A., Feltrin, F., Ianzano, A., Porrero, M. C., Liapi, M., and Battisti, A. (2011). Molecular characterization of spa type t127, sequence type 1 methicillin-resistant Staphylococcus aureus from pigs. J. Antimicrob. Chemother. 66, 1231-1235.

Garcia-Alvarez, L., Holden, M. T., Lindsay, H., Webb, C. R., Brown, D. F. Curran, M. D., Walpole, E., Brooks, K., Pickard, D. J., Teale, C., Parkhill, J., Bentley, S. D., Edwards, G. F., Girvan, E. K., Kearns, A. M., Pichon, B., Hill, R. L., Larsen, A. R., Skov, R. L., Peacock, S. J., Maskell, D. J., and Holmes, M. A. (2011). Methicillinresistant Staphylococcus aureus with a novel mecA homologue in human and bovine populations in the UK and Denmark: a descriptive study. Lancet Infect. Dis. 11, 595-603.

Garcia-Graells, C., Antoine, J., Larsen, J., Catry, B., Skov, R., and Denis, O. (2012). Livestock veterinarians at high risk of acquiring methicillin-resistant Staphylococcus aureus ST398. Epidemiol. Infect. 140, 383-389.

Gomez-Sanz, E., Torres, C., Lozano, C., Fernandez-Perez, R., Aspiroz, C., Ruiz-Larrea, F., and Zarazaga, M. (2010). Detection, molecular characterization, and clonal diversity of 
methicillin-resistant Staphylococcus aureus CC398 and CC97 in Spanish slaughter pigs of different age groups. Foodborne Pathog. Dis. 7, 1269-1277.

Grundmann, H., Aanensen, D. M., van den Wijngaard, C. C., Spratt, B. G., Harmsen, D., and Friedrich, A. W. (2010). Geographic distribution of Staphylococcus aureus causing invasive infections in Europe: a molecular-epidemiological analysis. PLoS Med. 7, e1000215. doi:10.1371/journal.pmed.1000215

Guardabassi, L., Stegger, M., and Skov, R. (2007). Retrospective detection of methicillin resistant and susceptible Staphylococcus aureus ST398 in Danish slaughter pigs. Vet. Microbiol. 122, 384-386.

Guinane, C. M., Ben Zakour, N. L., Tormo-Mas, M. A., Weinert, L. A., Lowder, B. V., Cartwright, R. A., Smyth, D. S., Smyth, C. J., Lindsay, J. A., Gould, K. A., Witney, A., Hinds, J., Bollback, J. P., Rambaut, A., Penades, J. R., and Fitzgerald, J. R. (2010). Evolutionary genomics of Staphylococcus aureus reveals insights into the origin and molecular basis of ruminant host adaptation. Genome Biol. Evol. 2, 454-466.

Hanselman, B. A., Kruth, S., and Weese, J. S. (2008). Methicillin-resistant staphylococcal colonization in dogs entering a veterinary teaching hospital. Vet. Microbiol. 126, 277-281.

Hanselman, B. A., Kruth, S. A., Rousseau, J., Low, D. E., Willey, B. M., McGeer, A., and Weese, J. S. (2006). Methicillin-resistant Staphylococcus aureus colonization in veterinary personnel. Emerging Infect. Dis. 12, 1933-1938.

Hanselman, B. A., Kruth, S. A., Rousseau, J., and Weese, J. S. (2009). Coagulase positive staphylococcal colonization of humans and their household pets. Can. Vet. J. 50, 954-958.

Hasman, H., Moodley, A., Guardabassi, L., Stegger, M., Skov, R. L., and Aarestrup, F. M. (2010). Spa type distribution in Staphylococcus aureus originating from pigs, cattle and poultry. Vet. Microbiol. 141, 326-331.

Hata, E., Katsuda, K., Kobayashi, H., Uchida, I., Tanaka, K., and Eguchi, M. (2010). Genetic variation among Staphylococcus aureus strains from bovine milk and their relevance to methicillin-resistant isolates from humans. J. Clin. Microbiol. 48, 2130-2139.

Herron-Olson, L., Fitzgerald, J. R., Musser, J. M., and Kapur, V. (2007). Molecular correlates of host specialization in Staphylococcus aureus. PLoS ONE 2, e1120. doi:10.1371/journal.pone.0001120

Horgan, M., Abbott, Y., Lawlor, P. G., Rossney, A., Coffey, A., Fitzgerald, G. F., McAuliffe, O., and Paul Ross, R. (2011). A study of the prevalence of methicillin-resistant Staphylococcus aureus in pigs and in personnel involved in the pig industry in Ireland. Vet. J. 190, 255-259.

Huber, H., Koller, S., Giezendanner, N., Stephan, R., and Zweifel, C. (2010). Prevalence and characteristics of methicillin-resistant Staphylococcus aureus in humans in contact with farm animals, in livestock, and in food of animal origin, Switzerland, 2009. Euro Surveill. 15, pii 19542.

Ito, T., Katayama, Y., Asada, K., Mori, N., Tsutsumimoto, K., Tiensasitorn, C., and Hiramatsu, K. (2001). Structural comparison of three types of staphylococcal cassette chromosome mec integrated in the chromosome in methicillin-resistant Staphylococcus aureus. Antimicrob. Agents Chemother. 45, 1323-1336.

Ito, T., Ma, X., Takeuchi, F., Okuma, K., Yuzawa, H., and Hiramatsu, K. (2004). Novel type V staphylococcal cassette chromosome mec driven by a novel cassette chromosome recombinase, $\mathrm{ccr}$ C. Antimicrob. Agents Chemother. 48, 2637-2651.

Jevons, M. (1961). “Celbenin”-resistant staphylococci. Br. Med. J. (Clin. Res. Ed.) 1, 124.

Juhasz-Kaszanyitzky, E., Janosi, S., Somogyi, P., Dan, A., van der Graafvan Bloois, L., van Duijkeren, E., and Wagenaar, J. A. (2007). MRSA transmission between cows and humans. Emerging Infect. Dis. 13, 630-632.

Kadlec, K., and Schwarz, S. (2009). Novel ABC transporter gene, vga $(C)$, located on a multiresistance plasmid from a porcine methicillin-resistant Staphylococcus aureus ST398 strain. Antimicrob. Agents Chemother. 53, 3589-3591.

Kadlec, K., and Schwarz, S. (2010). Identification of a plasmid-borne resistance gene cluster comprising the resistance genes $\operatorname{erm}(T)$, $d f r K$, and $\operatorname{tet}(L)$ in a porcine methicillin-resistant Staphylococcus aureus ST398 strain. Antimicrob. Agents Chemother. 54, 915-918.

Katayama, Y., Ito, T., and Hiramatsu, K. (2000). A new class of genetic element, staphylococcus cassette chromosome mec, encodes methicillin resistance in Staphylococcus aureus. Antimicrob. Agents Chemother. 44, 1549-1555.
Kehrenberg, C., Cuny, C., Strommenger, B., Schwarz, S., and Witte, W. (2009). Methicillin-resistant and -susceptible Staphylococcus aureus strains of clonal lineages ST398 and ST9 from swine carry the multidrug resistance gene cfr. Antimicrob. Agents Chemother. 53, 779-781.

Kennedy, A. D., Otto, M., Braughton, K. R., Whitney, A. R., Chen, L., Mathema, B., Mediavilla, J. R. Byrne, K. A., Parkins, L. D., Tenover, F. C., Kreiswirth, B. N., Musser J. M., and DeLeo, F. R. (2008). Epidemic community-associated methicillin-resistant Staphylococcus aureus: recent clonal expansion and diversification. Proc. Natl. Acad. Sci. U.S.A. 105, 1327-1332.

Khanna, T., Friendship, R., Dewey, C. and Weese, J. S. (2008). Methicillin resistant Staphylococcus aureus colonization in pigs and pig farmers. Vet. Microbiol. 128, 298-303.

Klevens, R. M., Edwards, J. R., Tenover, F. C., McDonald, L. C., Horan, T., and Gaynes, R. (2006). Changes in the epidemiology of methicillinresistant Staphylococcus aureus in intensive care units in US hospitals, 1992-2003. Clin. Infect. Dis. 42, 389-391.

Kluytmans, J. A. (2010). Methicillinresistant Staphylococcus aureus in food products: cause for concern or case for complacency? Clin. Microbiol. Infect. 16, 11-15.

Kock, R., Becker, K., Cookson, B., van Gemert-Pijnen, J. E., Harbarth, S., Kluytmans, J., Mielke, M., Peters, G. Skov, R. L., Struelens, M. J., Tacconelli, E., Navarro Torne, A., Witte, W., and Friedrich, A. W. (2010) Methicillin-resistant Staphylococcus aureus (MRSA): burden of disease and control challenges in Europe. Euro Surveill. 15, 19688.

Kock, R., Siam, K., Al-Malat, S., Christmann, J., Schaumburg, F., Becker, K., and Friedrich, A. W. (2011). Characteristics of hospital patients colonized with livestock-associated meticillin-resistant Staphylococcus aureus (MRSA) CC398 versus other MRSA clones. J. Hosp. Infect. 79 , 292-296.

Krziwanek, K., Metz-Gercek, S., and Mittermayer, H. (2009). Methicillinresistant Staphylococcus aureus ST398 from human patients, upper Austria. Emerging Infect. Dis. 15 766-769.

Lee, J. H. (2003). Methicillin (oxacillin)resistant Staphylococcus aureus strains isolated from major food animals and their potential transmission to humans. Appl. Environ. Microbiol. 69, 6489-6494.
Lina, G., Piemont, Y., Godail-Gamot, F., Bes, M., Peter, M., Gauduchon, V., Vandenesch, F., and Etienne, J. (1999). Involvement of Panton-Valentine leukocidinproducing Staphylococcus aureus in primary skin infections and pneumonia. Clin. Infect. Dis. 29, 1128-1132.

Loeffler, A., Boag, A. K., Sung, J., Lindsay, J. A., Guardabassi, L., Dalsgaard, A., Smith, H., Stevens, K. B., and Lloyd, D. H. (2005). Prevalence of methicillin-resistant Staphylococcus aureus among staff and pets in a small animal referral hospital in the UK. J. Antimicrob. Chemother. 56, 692-697.

Loeffler, A., Kearns, A. M., Ellington, M. J., Smith, L. J., Unt, V. E., Lindsay, J. A., Pfeiffer, D. U., and Lloyd, D. H. (2009). First isolation of MRSA ST398 from UK animals: a new challenge for infection control teams? J. Hosp. Infect. 72, 269-271.

Loeffler, A., and Lloyd, D. H. (2010). Companion animals: a reservoir for methicillin-resistant Staphylococcus aureus in the community? Epidemiol. Infect. 138, 595-605.

Loeffler, A., Pfeiffer, D. U., Lindsay, J. A., Magalhaes, R. J., and Lloyd, D. H (2011). Prevalence of and risk factors for MRSA carriage in companion animals: a survey of dogs, cats and horses. Epidemiol. Infect. 139, 1019-1028

Loeffler, A., Pfeiffer, D. U., Lindsay, J. A., Soares-Magalhaes, R., and Lloyd, D. H. (2010). Lack of transmission of methicillin-resistant Staphylococcus aureus (MRSA) between apparently healthy dogs in a rescue kennel. Vet. Microbiol. 141, 178-181.

Lowder, B. V., Guinane, C. M., Ben Zakour, N. L., Weinert, L. A., ConwayMorris, A., Cartwright, R. A., Simpson, A. J., Rambaut, A., Nubel, U., and Fitzgerald, J. R. (2009). Recent human-to-poultry host jump, adaptation, and pandemic spread of Staphylococcus aureus. Proc. Natl. Acad. Sci. U.S.A. 106, 19545-19550.

Ma, X., Ito, T., Tiensasitorn, C., Jamklang, M., Chongtrakool, P., BoyleVavra, S., Daum, R., and Hiramatsu, K. (2002). Novel type of staphylococcal cassette chromosome mec identified in community-acquired methicillin-resistant Staphylococcus aureus strains. Antimicrob. Agents Chemother. 46, 1147-1152.

McDougal, L. K., Steward, C. D., Killgore, G. E., Chaitram, J. M., McAllister, S. K., and Tenover, F. C. (2003). Pulsed-field gel electrophoresis typing of oxacillin-resistant Staphylococcus aureus isolates from the 
United States: establishing a national database. J. Clin. Microbiol. 41, 5113-5120.

Miller, L. G., Perdreau-Remington, F., Rieg, G., Mehdi, S., Perlroth, J., Bayer, A. S., Tang, A. W., Phung, T. O., and Spellberg, B. (2005). Necrotizing fasciitis caused by community-associated methicillin-resistant Staphylococcus aureus in Los Angeles. N. Engl. J. Med. 352, 1445-1453.

Monaco, M., Sanchini, A., Grundmann, H., and Pantosti, A. (2010). Vancomycin-heteroresistant phenotype in invasive methicillin-resistant Staphylococcus aureus isolates belonging to spa type 041. Eur. J. Clin. Microbiol. Infect. Dis. 29, 771-777.

Monecke, S., Coombs, G., Shore, A. C., Coleman, D. C., Akpaka, P., Borg, M., Chow, H., Ip, M., Jatzwauk, L., Jonas, D., Kadlec, K., Kearns, A., Laurent, F., O'Brien, F. G., Pearson, J., Ruppelt, A., Schwarz, S., Scicluna, E., Slickers, P., Tan, H. L., Weber, S., and Ehricht, R. (2011). A field guide to pandemic, epidemic and sporadic clones of methicillin-resistant Staphylococcus aureus. PLoS ONE 6, el7936. doi:10.1371/journal.pone.0017936

Monecke, S., Kuhnert, P., Hotzel, H., Slickers, P., and Ehricht, R. (2007). Microarray based study on virulence-associated genes and resistance determinants of Staphylococcus aureus isolates from cattle. Vet. Microbiol. 125, 128-140.

Moodley, A., Nielsen, S. S., and Guardabassi, L. (2011). Effects of tetracycline and zinc on selection of methicillin-resistant Staphylococcus aureus (MRSA) sequence type 398 in pigs. Vet. Microbiol. 152, 420-423.

Moon, J. S., Lee, A. R., Kang, H. M., Lee, E. S., Kim, M. N., Paik, Y. H., Park, Y. H., Joo, Y. S., and Koo, H. C. (2007). Phenotypic and genetic antibiogram of methicillin-resistant staphylococci isolated from bovine mastitis in Korea. J. Dairy Sci. 90, 1176-1185.

Moran, G. J., Krishnadasan, A., Gorwitz, R. J., Fosheim, G. E., McDougal, L. K., Carey, R. B., and Talan, D. A. (2006). Methicillin-resistant Staphylococcus aureus infections among patients in the emergency department. N. Engl. J. Med. 355, 666-674.

Morgan, M. (2008). Methicillinresistant Staphylococcus aureus and animals: zoonosis or humanosis? J. Antimicrob. Chemother. 62, 1181-1187.

Naimi, T. S., LeDell, K. H., ComoSabetti, K., Borchardt, S. M. Boxrud, D. J., Etienne, J., Johnson,
S. K., Vandenesch, F., Fridkin, S., O'Boyle, C., Danila, R. N., and Lynfield, R. (2003). Comparison of community- and health careassociated methicillin-resistant Staphylococcus aureus infection. JAMA 290, 2976-2984.

Nemati, M., Hermans, K., Lipinska, U., Denis, O., Deplano, A., Struelens, M., Devriese, L. A., Pasmans, F., and Haesebrouck, F. (2008). Antimicrobial resistance of old and recent Staphylococcus aureus isolates from poultry: first detection of livestock-associated methicillin-resistant strain ST398. Antimicrob. Agents Chemother. 52, 3817-3819.

Pan, A., Battisti, A., Zoncada, A., Bernieri, F., Boldini, M., Franco, A., Giorgi, M., Iurescia, M., Lorenzotti, S., Martinotti, M., Monaco, M., and Pantosti, A. (2009). Communityacquired methicillin-resistant Staphylococcus aureus ST398 infection, Italy. Emerging Infect. Dis. 15, 845-847.

Pantosti, A., Sanchini, A., and Monaco, M. (2007). Mechanisms of antibiotic resistance in Staphylococcus aureus. Future Microbiol. 2, 323-334.

Pishchany, G., McCoy, A. L., Torres, V. J., Krause, J. C., Crowe, J. E. Jr., Fabry, M. E., and Skaar, E. P. (2010). Specificity for human hemoglobin enhances Staphylococcus aureus infection. Cell Host Microbe 8, 544-550.

Porter, R. (1997). The Greatest Benefit to Mankind: A Medical History of Humanity. London: HarperCollins.

Rich, M., and Roberts, L. (2004). Methicillin-resistant Staphylococcus aureus isolates from companion animals. Vet. Rec. 154, 310.

Sanchini, A., Campanile, F., Monaco, M., Cafiso, V., Rasigade, J. P., Laurent, F., Etienne, J., Stefani, S., and Pantosti, A. (2011). DNA microarray-based characterisation of Panton-Valentine leukocidinpositive community-acquired methicillin-resistant Staphylococcus aureus from Italy. Eur. J. Clin. Microbiol. Infect. Dis. 30, 1399-1408.

Schnellmann, C., Gerber, V., Rossano, A., Jaquier, V., Panchaud, Y., Doherr, M. G., Thomann, A., Straub, R., and Perreten, V. (2006). Presence of new $m e c A$ and $m p h(C)$ variants conferring antibiotic resistance in Staphylococcus spp. isolated from the skin of horses before and after clinic admission. J. Clin. Microbiol. 44, 4444-4454.

Scott, G. M., Thomson, R., MaloneLee, J., and Ridgway, G. L. (1988). Cross-infection between animals and man: possible feline transmission of Staphylococcus aureus infection in humans? J. Hosp. Infect. 12, 29-34.

Shore, A. C., Deasy, E. C., Slickers, P., Brennan, G., O'Connell, B., Monecke, S., Ehricht, R., and Coleman, D. C. (2011). Detection of staphylococcal cassette chromosome mec type XI carrying highly divergent $m e c A$ mecI, mecRl, blaZ, and $c c r$ genes in human clinical isolates of clonal complex 130 methicillin-resistant Staphylococcus aureus. Antimicrob. Agents Chemother. 55, 3765-3773.

Smith, T. C., Male, M. J., Harper, A. L., Kroeger, J. S., Tinkler, G. P. Moritz, E. D., Capuano, A. W., Herwaldt, L. A., and Diekema, D. J. (2009). Methicillin-resistant Staphylococcus aureus (MRSA) strain ST398 is present in midwestern U.S. swine and swine workers. PLoS ONE 4, e4258. doi:10.1371/journal.pone. 0004258

Soavi, L., Stellini, R., Signorini, L., Antonini, B., Pedroni, P., Zanetti, L., Milanesi, B., Pantosti, A., Matteelli, A., Pan, A., and Carosi, G. (2010). Methicillin-resistant Staphylococcus aureus ST398, Italy. Emerging Infect. Dis. 16, 346-348.

Stegger, M., Lindsay, J. A., Sorum, M., Gould, K. A., and Skov, R. (2010). Genetic diversity in CC398 methicillin-resistant Staphylococcus aureus isolates of different geographical origin. Clin. Microbiol. Infect. 16, 1017-1019.

Sung, J. M., Lloyd, D. H., and Lindsay, J. A. (2008). Staphylococcus aureus host specificity: comparative genomics of human versus animal isolates by multi-strain microarray. Microbiology 154, 1949-1959.

Tenover, F. C., and Goering, R. V. (2009). Methicillin-resistant Staphylococcus aureus strain USA300: origin and epidemiology. J. Antimicrob. Chemother. 64, 441-446.

Tokateloff, N., Manning, S. T., Weese, J. S., Campbell, J., Rothenburger, J., Stephen, C., Bastura, V., Gow, S. P., and Reid-Smith, R. (2009). Prevalence of methicillin-resistant Staphylococcus aureus colonization in horses in Saskatchewan, Alberta, and British Columbia. Can. Vet. J. 50 1177-1180.

Tristan, A., Bes, M., Meugnier, H., Lina, G., Bozdogan, B., Courvalin, P., Reverdy, M. E., Enright, M. C., Vandenesch, F., and Etienne, J. (2007). Global distribution of PantonValentine leukocidin-positive methicillin-resistant Staphylococcus aureus, 2006. Emerging Infect. Dis. 13, 594-600.
Tsubakishita, S., Kuwahara-Arai, K., Sasaki, T., and Hiramatsu, K. (2010). Origin and molecular evolution of the determinant of methicillin resistance in staphylococci. Antimicrob. Agents Chemother. 54, 4352-4359.

Urth, T., Juul, G., Skov, R., and Schonheyder, H. C. (2005). Spread of a methicillin-resistant Staphylococcus aureus ST80-IV clone in a Danish community. Infect. Control Hosp. Epidemiol. 26, 144-149.

van Belkum, A., Melles, D. C., Peeters, J. K., van Leeuwen, W. B., van Duijkeren, E., Huijsdens, X. W., Spalburg, E., de Neeling, A. J., and Verbrugh, H. A. (2008). Methicillinresistant and -susceptible Staphylococcus aureus sequence type 398 in pigs and humans. Emerging Infect. Dis. 14, 479-483.

van Cleef, B. A., Monnet, D. L., Voss, A., Krziwanek, K., Allerberger, F., Struelens, M., Zemlickova, H., Skov, R. L., Vuopio-Varkila, J., Cuny, C., Friedrich, A. W., Spiliopoulou, I., Paszti, J., Hardardottir, H., Rossney, A., Pan, A., Pantosti, A., Borg, M., Grundmann, H., Mueller-Premru, M., Olsson-Liljequist, B., Widmer A., Harbarth, S., Schweiger, A., Unal, S., and Kluytmans, J. A. (2011). Livestock-associated methicillinresistant Staphylococcus aureus in humans, Europe. Emerging Infect. Dis. 17, 502-505.

van der Mee-Marquet, N., Francois, P., Domelier-Valentin, A. S., Coulomb, F., Decreux, C., Hombrock-Allet, C. Lehiani, O., Neveu, C., Ratovohery, D., Schrenzel, J., and Quentin, R. (2011). Emergence of unusual bloodstream infections associated with pig-borne-like Staphylococcus aureus ST398 in France. Clin. Infect. Dis. 52, 152-153.

van Duijkeren, E., Wolfhagen, M. J., Heck, M. E., and Wannet, W. J. (2005). Transmission of a PantonValentine leukocidin-positive, methicillin-resistant Staphylococcus aureus strain between humans and a dog. J. Clin. Microbiol. 43, 6209-6211.

van Loo, I., Huijsdens, X., Tiemersma E., de Neeling, A., van de SandeBruinsma, N., Beaujean, D., Voss, A., and Kluytmans, J. (2007). Emergence of methicillin-resistant Staphylococcus aureus of animal origin in humans. Emerging Infect. Dis. 13, 1834-1839.

van Wamel, W. J., Rooijakkers, S. H., Ruyken, M., van Kessel, K. P., and van Strijp, J. A. (2006). The innate immune modulators staphylococcal complement inhibitor and 
chemotaxis inhibitory protein of Staphylococcus aureus are located on beta-hemolysin-converting bacteriophages. J. Bacteriol. 188, 1310-1315.

Vandenesch, F., Naimi, T., Enright, M. C., Lina, G., Nimmo, G. R., Heffernan, H., Liassine, N., Bes, M., Greenland, T., Reverdy, M. E., and Etienne, J. (2003). Communityacquired methicillin-resistant Staphylococcus aureus carrying Panton-Valentine leukocidin genes: worldwide emergence. Emerging Infect. Dis. 9, 978-984.

Vanderhaeghen, W., Cerpentier, T., Adriaensen, C., Vicca, J., Hermans, K., and Butaye, P. (2010a). Methicillin-resistant Staphylococcus aureus (MRSA) ST398 associated with clinical and subclinical mastitis in Belgian cows. Vet. Microbiol. 144, 166-171.

Vanderhaeghen, W., Hermans, K., Haesebrouck, F., and Butaye, P. (2010b). Methicillin-resistant Staphylococcus aureus (MRSA) in food production animals. Epidemiol. Infect. 138, 606-625.

Vengust, M., Anderson, M. E., Rousseau, J., and Weese, J. S. (2006). Methicillin-resistant staphylococcal colonization in clinically normal dogs and horses in the community. Lett. Appl. Microbiol. 43, 602-606.

Viana, D., Blanco, J., Tormo-Mas, M. A., Selva, L., Guinane, C. M., Baselga, R., Corpa, J. M., Lasa, I., Novick, R. P., Fitzgerald, J. R., and Penades, J. R. (2010). Adaptation of Staphylococcus aureus to ruminant and equine hosts involves SaPI-carried variants of von Willebrand factor-binding protein. Mol. Microbiol. 77, 1583-1594.

Voss, A., Loeffen, F., Bakker, J., Klaassen, C., and Wulf, M. (2005). Methicillinresistant Staphylococcus aureus in pig farming. Emerging Infect. Dis. 11, 1965-1966.

Voyich, J. M., Otto, M., Mathema, B., Braughton, K. R., Whitney, A. R., Welty, D., Long, R. D., Dorward, D. W., Gardner, D. J., Lina, G., Kreiswirth, B. N., and DeLeo, F. R. (2006). Is Panton-Valentine leukocidin the major virulence determinant in community-associated methicillin-resistant Staphylococcus aureus disease? J. Infect. Dis. 194, 1761-1770.

Wagenaar, J. A., Yue, H., Pritchard, J. Broekhuizen-Stins, M., Huijsdens, X., Mevius, D. J., Bosch, T., and Van Duijkeren, E. (2009). Unexpected sequence types in livestock associated methicillin-resistant Staphylococcus aureus (MRSA): MRSA ST9 and a single locus variant of ST9 in pig farming in China. Vet. Microbiol. 139, 405-409.

Wassenberg, M. W., Bootsma, M. C., Troelstra, A., Kluytmans, J. A., and Bonten, M. J. (2011). Transmissibility of livestock-associated methicillin-resistant Staphylococcus aureus (ST398) in Dutch hospitals. Clin. Microbiol. Infect. 17, 316-319.

Weese, J. S. (2010). Methicillin-resistant Staphylococcus aureus in animals. ILAR J. 51, 233-244.

Weese, J. S., Caldwell, F., Willey, B. M., Kreiswirth, B. N., McGeer,
A., Rousseau, J., and Low, D. E. (2006). An outbreak of methicillinresistant Staphylococcus aureus skin infections resulting from horse to human transmission in a veterinary hospital. Vet. Microbiol. 114 160-164.

Weese, J. S., Rousseau, J., TraubDargatz, J. L., Willey, B. M., McGeer, A. J., and Low, D. E. (2005). Community-associated methicillinresistant Staphylococcus aureus in horses and humans who work with horses. J. Am. Vet. Med. Assoc. 226 580-583.

Welinder-Olsson, C., Floren-Johansson, K., Larsson, L., Oberg, S., Karlsson, L., and Ahren, C. (2008). Infection with Panton-Valentine leukocidin-positive methicillinresistant Staphylococcus aureus $\mathrm{t} 034$. Emerging Infect. Dis. 14, 1271-1272.

Witte, W., Strommenger, B., Stanek, C. and Cuny, C. (2007). Methicillinresistant Staphylococcus aureus ST398 in humans and animals, Central Europe. Emerging Infect. Dis. 13, 255-258.

Wulf, M. W., Markestein, A., van der Linden, F. T., Voss, A., Klaassen, C., and Verduin, C. M. (2008a). First outbreak of methicillin-resistant Staphylococcus aureus ST398 in a Dutch hospital, June 2007. Euro Surveill. 13, pii 8051.

Wulf, M. W., Sorum, M., van Nes, A., Skov, R., Melchers, W. J., Klaassen, C. H., and Voss, A. (2008b). Prevalence of methicillin-resistant Staphylococcus aureus among veterinarians: an international study. Clin. Microbiol. Infect. 14, 29-34.
Yu, F., Chen, Z., Liu, C., Zhang, X., Lin, X., Chi, S., Zhou, T., Chen, Z., and Chen, X. (2008). Prevalence of Staphylococcus aureus carrying Panton-Valentine leukocidin genes among isolates from hospitalised patients in China. Clin. Microbiol. Infect. 14, 381-384.

Zemlickova, H., Fridrichova, M., Tyllova, K., Jakubu, V., and Machova, I. (2009). Carriage of methicillin-resistant Staphylococcus aureus in veterinary personnel. Epidemiol. Infect. 137, 1233-1236.

Conflict of Interest Statement: The author declares that the research was conducted in the absence of any commercial or financial relationships that could be construed as a potential conflict of interest.

Received: 09 December 2011; accepted: 18 March 2012; published online: 09 April 2012.

Citation: Pantosti A (2012) Methicillinresistant Staphylococcus aureus associated with animals and its relevance to human health. Front. Microbio. 3:127. doi: 10.3389/fmicb.2012.00127

This article was submitted to Frontiers in Antimicrobials, Resistance and Chemotherapy, a specialty of Frontiers in Microbiology.

Copyright (c) 2012 Pantosti. This is an open-access article distributed under the terms of the Creative Commons Attribution Non Commercial License, which permits non-commercial use, distribution, and reproduction in other forums, provided the original authors and source are credited. 